\title{
Double Minutes Arise from Circular Extrachromosomal DNA Intermediates Which Integrate into Chromosomal Sites in Human HL-60 Leukemia Cells
}

\author{
D. D. Von Hoff, B. Forseth, C. N. Clare,* K. L. Hansen, * and D. VanDevanter \\ Division of Oncology, Department of Medicine and ${ }^{*}$ Department of Pathology, University of Texas \\ Health Science Center at San Antonio, San Antonio, Texas 78284-7884
}

\begin{abstract}
Amplification of oncogenes has been found to be an important prognostic factor in behavior of patients' malignancies. In this study we have used new gel electrophoresis techniques to follow the location of amplified c-myc oncogene sequences in HL-60 promyelocytic leukemia cells. In passages 46-62 of the cells, the cells contain amplified c-myc sequences on submicroscopic circular extrachromosomal DNA (episomes). With increased passages in culture (passages 63-72) the cells lose the episome c-myc sequences with a shift of those sequences to double minutes. With additional passage in culture, the c-myc shifts from the double minutes to a chromosomal site $\operatorname{der}(5) t(5 ; 17)(q 11.2 ; q ? 11.2)$. Concomitant with the shift of the c-myc sequences into the chromosomal compartment is a phenotypic change of a shortened cell-doubling time. These studies provide the first molecular evidence of a progression from a submicroscopic location for amplified oncogene sequences to a chromosomal location for the amplified sequences.

This molecularly documented model can now be used to test various strategies to prevent incorporation of extrachromosomally located oncogene sequences into chromosomal sites. Prevention of integration of the oncogene sequences into chromosomal sites could modulate progression of patients' tumors. (J. Clin. Invest. 1990. 85:1887-1895.) oncogene • c-myc • gene amplification • episomes $\bullet$ homogeneously staining regions
\end{abstract}

\section{Introduction}

Gene amplification is a mechanism whereby transformed cells generate multiple copies of discrete regions of their genome. This amplification gives an increase in titers of gene product(s) coded for within the amplified regions $(1,2)$. Gene amplification has been demonstrated to be important in vitro and in vivo for resistance of patients' tumors to antineoplastic agents (via amplification of drug resistance genes) and for progression of patients' tumors (via amplification of oncogenes) (3-7).

There are two cytogenetic manifestations of gene amplifi-

Dr. VanDevanter's current address is Tumor Institute, Swedish Hospital Medical Center, Seattle, WA 98104.

Address reprint requests to Dr. Von Hoff, Medicine/Oncology, University of Texas Health Science Center at San Antonio, 7703 Floyd Curl Drive, San Antonio, TX 78284-7884.

Received for publication 30 August 1989 and in revised form 23 January 1990

J. Clin. Invest.

(c) The American Society for Clinical Investigation, Inc.

0021-9738/90/06/1887/09 \$2.00

Volume 85, June 1990, 1887-1895 cation. These include double minutes (DMs) ${ }^{1}$ and homogeneously staining regions (HSRs) $(8,9)$. Amplified drug resistance genes and amplified oncogenes have been localized to these structures.

DMs were first described by Spriggs et al. in 1962 (10). They are extrachromosomal chromatin bodies which lack centromeres and consequently have unequal separation at cell division. DMs have a wide variation in size even in a specific cell line. In addition, there is also a great variation in the number of DMs per cell $(8,9)$.

HSRs were first described by Biedler and Spengler in 1976 $(11,12)$. HSRs are an intrachromosomal abnormality in which regions of chromosomes stain in a uniform manner rather than in the usual differential banding pattern characteristic of G-band preparations. Within a cell line, HSRs tend to occur most commonly on specific chromosomes. Like DMs, HSRs appear to replicate early in $\mathrm{S}$ phase.

The origin of DMs is unclear. They have been considered as artifacts, microbial contamination, breakdown products of chromosomes, or fragments of $\operatorname{HSRs}(1,13,14)$. The origin of HSRs is also unclear. There is some evidence that suggest HSRs may be generated by unequal crossing over between sister chromatids $(15,16)$. Another mechanism involves saltatory replication whereby replication can be initiated at the same origin a number of times during one replication. Multiple initiations of replication generates an "onion skin" structure which together with recombination into the chromosome could generate duplicated sequences at the site of the specific gene (17). Several investigators have documented, using cytogenetic methods in a variety of systems, that HSRs appear to arise from a chromosomal integration of DMs (see discussion below).

In recent months some new molecular evidence has been reported which may give a clue as to the origin of both DMs and HSRs. In a Chinese hamster ovary (CHO) cell line resistant to the antineoplastic agent $N$-phosphonacetyl-L-aspartate (based on amplification of the CAD gene), Carroll and colleagues (18) have reported no chromosomal localization for the amplified CAD sequence but rather localization of the sequences on replicating circular submicroscopic supercoiled DNA. The same team has provided molecular and cytogenetic evidence that these circular DNAs (termed episomes) replicate and form double minutes in that $\mathrm{CHO}$ line (19). Episomes containing drug resistant genes have now also been documented to be present in human tumor cells with amplification

1. Abbreviations used in this paper: ABR, abnormal banding region; CAD, multifunctional protein that catalyzes the first three steps in de novo UMP biosynthesis; CHEF, contour-clamped homogeneous electric field (electrophoresis); DMs, double minutes; FIGE, field inversion gel electrophoresis; HSRs, homogeneously staining regions; TE, TrisEDTA. 
of the dihydrofolate reductase gene (20-22) and with amplification of the multidrug resistance gene $(22,23)$.

Most recently, we have reported that passages 36-46 of the HL-60 human promyelocytic leukemia line, which has amplified copies of the c-myc oncogene, has those copies of the gene located on extrachromosomal replicating supercoiled circular DNA (episomes) $\sim 250 \mathrm{kbp}$ in size (24). In the present study, we have used molecular and cytogenetic techniques to follow the fate of those episomal elements as the HL-60 cells are passaged in tissue culture. We have found that with increasing passage in culture the c-myc-containing episomes are replaced by c-myc-containing DMs. With additional time the c-myc sequences on the DMs move from their extrachromosomal site and integrate into the short arm of the $\operatorname{der}(5) \mathrm{t}(5 ; 17)$ chromosome. Coincidentally with chromosomal c-myc incorporation there is a shortening of the population doubling time, indicating a more rapidly dividing cell population. The present finding that an oncogene sequence can shift from an extrachromosomal compartment (where it has potential to be lost in the dividing cell, e.g., is unstable) to an intrachromosomal compartment (where it is not lost on cell division, e.g., is stable) provides a model in which to study methods to prevent that integration. Prevention of integration of an oncogene sequence into the chromosomal compartment could potentially modulate tumor growth.

\section{Methods}

Cell lines

Passage 46 of the HL-60 promyelocytic leukemia cell line (growing in RPMI media with $10 \%$ FBS) was provided in a T25 flask by Dr. Steve Collins at the University of Washington, Seattle, WA (25). This cell line contains approximately 16-32 copies of the c-myc oncogene (26). To establish subclones from the parental cell line, the cells were diluted so that approximately three to five cells were placed in each well of 96-well titer plates. The subclones were grown at $37^{\circ} \mathrm{C}$ in $5 \% \mathrm{CO}_{2}$ in RPMI medium enriched with $20 \%$ FBS. A total of 186 wells were initially seeded. The cells from 12 of these wells were selected for expansion. The subclones selected for expansion had the best percent recovery of episomal DNA by the alkaline lysate method described below. After several population doublings (see below), cells were transferred to six-well dishes and then to T-25 flasks. Growth medium was changed to RPMI + 10\% FBS in the flasks and cells were diluted 1:4 with the fresh medium once per week. Each of the subclones was numbered and continued in passage. Two of the subclones (nos. 173 and 161) were selected for serial molecular analysis, again based on the greatest intensity of the c-myc signal (on Southern blots) for form I (supercoiled episome) in those subclones (see below).

As a control cell line, we utilized the C5R500 CHO cell line (18) kindly supplied by Dr. Geoffrey Wahl at the Salk Institute, La Jolla, CA. This cell line contains a 250-kbp episome containing the CAD gene.

\section{Alkaline lysis}

This technique was used to isolate the episomal DNA. Cells were removed from culture and washed with PBS. Cell counts were performed and $2.0 \times 10^{7}$ cells were lysed under alkaline conditions using vortexing at a pH of 12.45 for $2 \mathrm{~min}$ in $2 \mathrm{ml}$ of $1 \% \mathrm{SDS}, 50 \mathrm{mM} \mathrm{NaCl}$, and $25 \mathrm{mM}$ EDTA $(18,24)$. Samples were then incubated for $30 \mathrm{~min}$ at $30^{\circ} \mathrm{C}$ and then neutralized with $0.4 \mathrm{ml}$ of $1.0 \mathrm{M}$ Tris $\mathrm{HCl}, \mathrm{pH} 7.0$ (all chemicals from Sigma Chemical Co., St. Louis, MO). Lysates were treated with $0.3 \mathrm{ml}$ of $5 \mathrm{M} \mathrm{NaCl}$ and $14 \mu \mathrm{l}$ of $20 \mathrm{mg} / \mathrm{ml}$ proteinase $\mathrm{K}$ (Sigma Chemical Co.) and incubated for $30 \mathrm{~min}$ at $37^{\circ} \mathrm{C}$. Phenol (saturated with $0.2 \mathrm{M} \mathrm{NaCl}, 0.2 \mathrm{M}$ Tris $\mathrm{HCl}$ at $\mathrm{pH} 8)(0.8 \mathrm{ml})$ was added, samples were mixed, and lysates were spun at $10,000 \mathrm{~g}$ for 10 $\min$ at $4^{\circ} \mathrm{C}$. Aqueous phases were transferred to new tubes, 2.5 vol of $100 \%$ ethanol were added, and samples were stored at $-20^{\circ} \mathrm{C}$ over- night. DNA was precipitated by centrifugation at $10,000 \mathrm{~g}$ for $10 \mathrm{~min}$ at $4^{\circ} \mathrm{C}$, rinsed with $1 \mathrm{ml}$ of $70 \%$ ethanol, spun-dried, and resuspended in TE buffer. Samples were made $5 \%$ with respect to glycerol for electrophoresis.

\section{Preparation and irradiation of DNA in agarose blocks}

Cells were harvested, rinsed with PBS, and suspended in PBS at a density of $2.5 \times 10^{7}$ cells $/ \mathrm{ml}$. Cell suspensions were mixed with an equal volume of molten $\left(55^{\circ} \mathrm{C}\right) 1 \%$ low melting point agarose (SeaPlaque, FMC Corporation, Rockland, ME) in PBS and pipetted in $40-\mu l$ aliquots $\left(5 \times 10^{5}\right.$ cells $)$ into a rubber-based block-forming mold (27). Blocks were allowed to harden and were placed in $15-\mathrm{ml}$ culture tubes containing $2 \mathrm{ml}$ of $1 \%$ Sarkosyl (Sigma Chemical Co.), $100 \mathrm{mM}$ EDTA. Proteinase $\mathrm{K}(2 \mathrm{mg} / \mathrm{ml})$ was added, the blocks were incubated for $24 \mathrm{~h}$ at $55^{\circ} \mathrm{C}$, rinsed twice with $10 \mathrm{ml}$ of TE, and stored in TE at $4^{\circ} \mathrm{C}$. Blocks were placed in $100 \mu \mathrm{l}$ of TE in $1.5-\mathrm{ml}$ microfuge tubes, and irradiated by ${ }^{137} \mathrm{Cs}$ source (Gamma Cell 40 , Atomic Energy of Canada Ltd., Ottawa, Canada) at a dose of $1.2 \mathrm{~Gy} / \mathrm{min}$ for $6 \mathrm{~min}$ before electrophoresis.

\section{DNA electrophoresis}

Alkaline lysate DNA was electrophoresed in $0.8 \%$ agarose (Ultra Pure, Bethesda Research Laboratories, Gaithersburg, MD) using electrophoretic gels run in $45 \mathrm{mM}$ Tris borate, $1 \mathrm{mM}$ EDTA, pH $8.3(0.5$ $\times$ TBE) buffer with recirculation at room temperature at a field strength of $1.7 \mathrm{~V} / \mathrm{cm}$ for $24 \mathrm{~h}$. Episomal DNA molecules embedded in agarose blocks and linearized by ${ }^{137} \mathrm{Cs}$ irradiation were electrophoresed by either field inversion gel electrophoresis (FIGE, resolving molecules below $1,000 \mathrm{kbp}$ in size) or contour-clamped homogeneous electric field (CHEF, resolving molecules between 1,000 and $9,000 \mathrm{kbp}$ in size) electrophoretic strategies $(22,28,29)$. FIGE was performed using a pulse switcher (Hoefer Scientific Instruments, San Francisco, CA) at 7 $\mathrm{V} / \mathrm{cm}$ with a $3: 1$ forward to reverse pulse ratio in $1 \%$ agarose gels at $14^{\circ} \mathrm{C}$ with buffer recirculation. Pulses were ramped linearly from $3 \mathrm{~s}$ forward to $60 \mathrm{~s}$ forward over $12 \mathrm{~h}$. CHEF electrophoresis was performed using a CHEF-II DR apparatus (Bio-Rad Laboratories, Richmond, CA) in $0.6 \%$ agarose gels at $14^{\circ} \mathrm{C}$ with 60 -min pulses for $158 \mathrm{~h}$ at $50 \mathrm{~V}$. Molecular weights between 200 and $1,100 \mathrm{kbp}$ were determined by electrophoresing the chromosomes of Saccharomyces cerevisiae (Beckman Instruments, Inc., Houston, TX). Linearized Escherichia coli chromosome was used as a 4,800-kbp marker (30). Gels were stained for $30 \mathrm{~min}$ in $1.0 \mu \mathrm{g} / \mathrm{ml}$ ethidium bromide and photographed with a red filter by transillumination with a $300-\mathrm{nm}$ wavelength UV source.

\section{DNA transfer and hybridization}

DNA was transferred from agarose gels to nylon-66 membranes ( $\mathrm{Ny}-$ tran, Schleicher \& Schuell, Inc., Keene, $\mathrm{NH}$ ) by alkaline capillary transfer. Gels were equilibrated in $0.5 \mathrm{M} \mathrm{NaOH}, 1.5 \mathrm{M} \mathrm{NaCl}$ (transfer buffer) for $30 \mathrm{~min}$ at room temperature and placed on top of two pieces of wetted 3MM chromatography paper (Whatman Inc., Clifton, NJ) draped into transfer buffer. Nylon-66 membrane was wetted in water and then transfer buffer, placed on top of agarose gels, and covered with two pieces of $3 \mathrm{MM}$ paper wetted in transfer buffer. Six inches of paper towels and a 500-g weight were placed on top, and transfers were allowed to proceed overnight. Membranes were baked $30 \mathrm{~min}$ at $80^{\circ} \mathrm{C}$ in vacuo. Membranes were hybridized with specific DNA probes labeled with ${ }^{32} \mathrm{P}$ by nick-translation kit (Boehringer Mannheim Biochemicals, Indianapolis, IN) to a specific activity of $>10^{8} \mathrm{dpm} / \mu \mathrm{g}$ as previously described (31). Hybridized membranes were matted with X-ray film (X-OMAT, Eastman Kodak Co., Rochester, NY) between two intensifying screens (Lightning Plus, DuPont Co., Wilmington, DE) and incubated at $-70^{\circ} \mathrm{C}$ to generate autoradiograms.

\section{DNA probes}

Nylon membranes were probed for c-myc sequences using a commercially available probe (Oncor, Gaithersburg, MD) for the third exon of human c-myc. The PET 5 probe (a gift from Dr. Geoff Wahl) was used to probe for mitochondrial DNA. 


\section{DM and karyotype analysis}

HL-60 cells in log phase of growth were harvested by a modification of the trypsin-hypotonic-colcemid (THC) technique of Hozier and Lindquist (32). Cells were incubated in $10 \mathrm{ml}$ of a $1: 90.25 \%$ trypsin/ 0.075 $\mathrm{M} \mathrm{KCl}$ solution containing $0.1 \mu \mathrm{g} / \mathrm{ml}$ colcemid (Gibco Laboratories, Grand Island, NY) for $1 \mathrm{~h}$ at $37^{\circ} \mathrm{C}$. After fixation with 3:1 methanol/ acetic acid, cells were dropped on clean wet slides and dried on a $60^{\circ} \mathrm{C}$ slide warmer. Slides for DM analysis' were stained with $2 \%$ Giemsa (Harleco, EM Science, Gibbstown, NJ). Slides for karyotype analysis were aged at room temperature for $7-10 \mathrm{~d}$ or heated at $60^{\circ} \mathrm{C}$ for $72 \mathrm{~h}$ before trypsin-Giemsa banding.

50 metaphase spreads from each passage were examined for the presence of DMs. The DMs were categorized by size on a scale of 1-5 $(1$, just barely visible with $100 \times$ oil immersion; and 5 , just smaller than the width of a chromatid). The number of pairs in each size category was also recorded. A minimum of 20 metaphase spreads from each passage was also analyzed for karyotyping after trypsin-Giemsa banding. The cytogeneticist was blinded to the molecular probing results for each passage.

HL-60 in situ mapping of c-myc adapted from technique of Pinkel et al. (33)

Metaphase spreads. HL-60 cells in log phase growth were incubated for $20 \mathrm{~min}$ in $10 \mu \mathrm{g} / \mathrm{ml}$ ethidium bromide at $37^{\circ} \mathrm{C}$. Colcemid $(0.1 \mu \mathrm{g} / \mathrm{ml})$ was added, cells were incubated an additional $20 \mathrm{~min}$, and cells were pelleted. Cell pellets were suspended in $37^{\circ} \mathrm{C} 0.075 \mathrm{M} \mathrm{KCl}$, incubated for $20 \mathrm{~min}$, and pelleted again. Cell pellets were suspended in fixative (fresh 3:1 methanol/glacial acetic acid), incubated at room temperature for $\mathbf{2 0} \mathrm{min}$, pelleted, and resuspended in fixative. Suspended cells were stored overnight at $4^{\circ} \mathrm{C}$.

Metaphase spreads were made by pelleting cells, resuspending in fresh fixative, and dropping suspended cells on clean microscope slides. Slides were air-dried and stored for $10 \mathrm{~d}$ at room temperature to age.

Chromosome denaturation. Metaphase spreads on microscope slides were treated with $150 \mu \mathrm{l}$ of $100 \mu \mathrm{g} / \mathrm{ml} \mathrm{RNase} \mathrm{(Sigma} \mathrm{Chemical}$ Co. $)$ in $2 \times \mathrm{SSC}, \mathrm{pH} 7$, under a coverslip $(24 \times 50 \mathrm{~mm})$ at $37^{\circ} \mathrm{C}$ in a moist chamber for $1 \mathrm{~h}$. Slides were rinsed in four changes of $2 \times \mathrm{SSC}$, pH 7, at room temperature, dehydrated by incubating for $2 \mathrm{~min}$ in $70 \%, 85 \%$, and $100 \%$ ethanol (consecutively), and dried with an air jet. Metaphases were treated with $150 \mu \mathrm{l}$ of $0.5 \mu \mathrm{g} / \mathrm{ml}$ proteinase K (Sigma Chemical Co.) in $20 \mathrm{mM}$ Tris $\mathrm{HCl}, 2 \mathrm{mM} \mathrm{CaCl}_{2}, \mathrm{pH} 7.5$, for $7.5 \mathrm{~min}$ at $37^{\circ} \mathrm{C}$ under a coverslip, washed in $2 \times \mathrm{SSC}$, fixed in $4 \%$ paraformaldehyde (in $50 \mathrm{mM} \mathrm{MgCL}, 1 \times \mathrm{PBS}, \mathrm{pH} 7.5$ ) for $10 \mathrm{~min}$, and rinsed in $2 \times$ SSC.

Chromosomes were denatured by immersing slides in $70 \%$ formamide (Sigma Chemical Co.), $2 \times \mathrm{SSC}, \mathrm{pH} 7$, for 2 min at $70^{\circ} \mathrm{C}$. Slides were quickly transferred to $70 \%$ ethanol for $1 \mathrm{~min}$, followed by $85 \%$ ethanol and then $100 \%$ ethanol, also for $1 \mathrm{~min}$, and then dried by air jet.

Biotin labeling of c-myc probe. $1 \mu \mathrm{g}$ of $\mathrm{pSV}-m y c$ (a plasmid containing a simian virus promoter along with c-myc sequence) was labeled with biotin by incubation with $2.5 \mu \mathrm{l}$ of dCTP, dATP, and dGTP from the Boehringer Mannheim nick kit, in addition to $5 \mu \mathrm{l}$ of $10 \times$ nick buffer and $1 \mu \mathrm{l}$ of biotin-16-dUTP (Boehringer Mannhein). Tritiated dATP $(1 \mu \mathrm{l} ; 250,000 \mathrm{cpm})$ was also added to follow biotin incorporation. The nick volume was made up to $45 \mu \mathrm{l}$, and $5 \mu \mathrm{l}$ of nick enzyme was added. The reaction proceeded at $15^{\circ} \mathrm{C}$ for $90 \mathrm{~min}$ and was stopped by addition of $10 \mu \mathrm{l}$ of $0.1 \mathrm{M}$ EDTA. DNA was separated from unincorporated dNTPs by chromatography on BioGel P-60 resin (BioRad Laboratories) in TE, pH 7.5. Fractions were scintillation counted $\left({ }^{3} \mathrm{H}\right.$ window), and $400 \mu \mathrm{l}$ of labeled DNA $(2.5 \mu \mathrm{g} / \mathrm{ml})$ was collected for hybridization to HL-60 chromosomes.

Hybridization. Deproteinated and denatured HL-60 metaphase chromosomes were hybridized with biotin-labeled pSVc-myc probe by incubation at $37^{\circ} \mathrm{C}$ at a concentration of $100 \mathrm{ng}$ of labeled probe/ml of hybridization mix (10\% dextran sulfate, $50 \%$ formamide [Sigma Chemical Co.], $2 \times$ SSC, and $50 \mu \mathrm{g} / \mathrm{ml}$ denatured herring testes DNA
[Sigma Chemical Co.]) under a glass coverslip. Labeled probe and carrier DNA were denatured by making them $0.1 \mathrm{~N}$ with respect to $\mathrm{NaOH}$ and incubating at $37^{\circ} \mathrm{C}$ for $10 \mathrm{~min}$ before addition to the hybridization mix. Hybridization mix ( $30 \mu \mathrm{l}$ per slide) was placed on slides warmed to $37^{\circ} \mathrm{C}$, and coverslips $(24 \times 50 \mathrm{~mm})$ were placed on top and sealed with rubber cement. Hybridizations were allowed to proceed overnight at $37^{\circ} \mathrm{C}$ in a tissue culture incubator, and slides were washed with three changes of $50 \%$ formamide, $2 \times \mathrm{SSC}, \mathrm{pH} 7$, at $45^{\circ} \mathrm{C}$ for $2 \mathrm{~min}$ each, once in room temperature $2 \times \mathrm{SSC}$ for $2 \mathrm{~min}$, and then placed in $0.1 \mathrm{M}$ sodium phosphate, $0.1 \% \mathrm{NP}-40, \mathrm{pH} 8.0$ (PN buffer) until ready for staining.

Slide staining. All subsequent manipulations were performed in a room with very low light levels. Slides were removed from PN buffer, drained briefly, and $75 \mu \mathrm{l} \mathrm{of} 5 \mu \mathrm{g} / \mathrm{ml}$ fluorescein-labeled avidin (Vector Laboratories, Inc., Burlingame, CA) in PN buffer containing 5\% nonfat dry milk (PNM buffer) was added, followed by a glass coverslip ( 24 $\times 50 \mathrm{~mm}$ ). The slide was incubated for $20 \mathrm{~min}$ at room temperature in a moist chamber, and then washed in three changes of PN buffer for 2 min each. Slides were drained, and $75 \mu \mathrm{l}$ of $5 \mu \mathrm{g} / \mathrm{ml}$ biotinylated goat anti-avidin (Vector Laboratories, Inc.) in PNM buffer was incubated under a coverslip for $\mathbf{2 0} \mathrm{min}$ at room temperature. Slides were washed in three changes of PN buffer, and cycles of avidin, anti-avidin, and then avidin labeling separated by PN buffer washes were repeated again. Slides were washed once again in three changes of PN buffer, drained well (but not dried), and stained with $22 \mu \mathrm{l}$ of antifade containing $0.2 \mu \mathrm{g} / \mathrm{ml}$ propidium iodide covered with a no. 1 glass coverslip $(24 \times 50 \mathrm{~mm})$.

Chromosomes could be viewed immediately by fluorescent scope at 64 power under oil using the appropriate filter (FITC). Metaphases were photographed with Ecktachrome $\mathbf{4 0 0}$ slide film (Eastman Kodak Co.) with $\sim 15$-s exposures.

Borate banding. After fluorescent staining and photography, chromosomes were banded by soaking slides extensively in borate buffer and then staining in Giemsa (Harleco) diluted 1:3 in borate buffer. Chromosome morphology is very poor after proteinase $\mathrm{K}$ and denaturation/hybridization, but banding patterns could be determined for some metaphases.

\section{Results}

Fate of episomal DNA. As discussed above we have previously documented that passages 36-62 of HL-60 cells have c-myc sequences located on supercoiled extrachromosomal DNA $\sim 250 \mathrm{kbp}$ in size (episomes). The parent HL-60 line and the series of 12 subclones of the HL-60 were reexamined to document that they indeed had c-myc sequences located on episomal DNA (Fig. 1). As can be seen in this figure all 13 cell lines had evidence of an episome containing c-myc sequence in early passages (48-62) of the cells.

Two of these subclones (nos. 173 and 161) were followed in serial passages for the presence of $c-m y c$ on episomes. As can be seen in Fig. 2, there was a decline in the amount of c-myc located on episomal DNA from an average of 400 density units in passage 63 cells down to essentially no c-myc present on episomal DNA by passage 73. Fig. 3 provides molecular evidence for this finding in one of the subclones (clone no. 173). Thus, with increasing passage number, the amount of c-myc present on episomal DNA was declining even though the total c-myc present in the cell line was staying about the same (13-fold amplification). Thus the c-myc sequences must have been shifting out of the episomal compartment into some other compartment.

As has been discussed in the introduction, Carroll and colleagues (19) had noted that the CAD gene present as episomal DNA in CHO cells appeared to be precursors for DMs when 


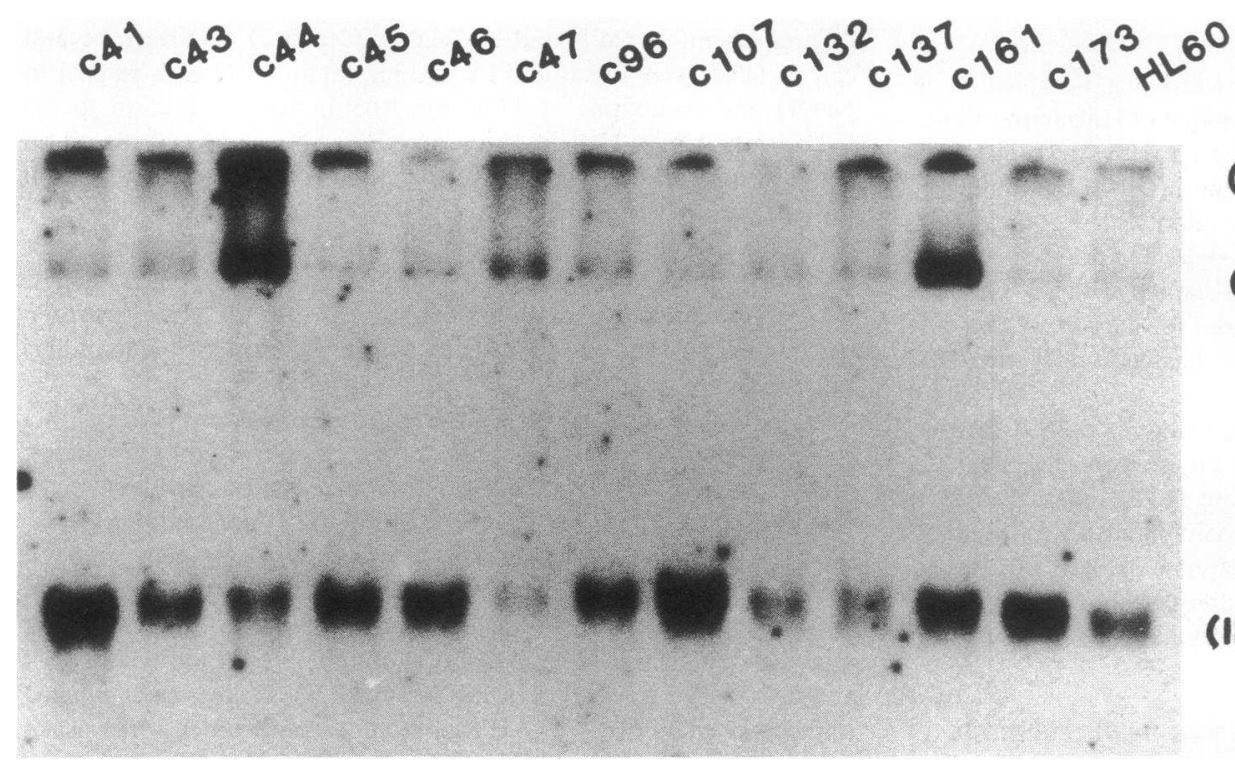

Figure 1. Parent line HL-60 and 12 subclones were examined to determine whether or not they contained episomal c-myc. All lines were pro(II) cessed using an alkaline lysate technique (see text) to isolate circular extrachromosomal DNA. The alkaline lysate material was run on a conventional gel $5-6 \mathrm{~V} / \mathrm{cm}$ for $17 \mathrm{~h}$ at room temperature. Southern transfers from the gel were hybridized with a c-myc probe. All subclones demonstrated evidence of episomal DNA (different amounts because different number of cells of each clone were processed). The episomal DNA was present in three different forms including form I (supercoiled), form II (open circular which cannot migrate into the gel under the standard electrophoresis technique used), and form III which represents the linearized form of the circle. A reprobe of this blot with an actin sequence did not detect the episomal molecule, indicating the bands noted are specific for the c-myc sequence.

the cells were passaged under selective pressure with the drug $N$-phosphonacetyl-L-aspartate. To determine if the c-myc sequence in the HL-60 cells may have transferred to DM DNA we examined metaphase spreads of each passage of subclones 173 and 161 to determine whether or not DMs were present. As can be seen in Fig. 4, the percentage of HL-60 cells with DMs increased from about $20 \%$ at passage 60 to about $75 \%$ by passage 68 . The average number of DMs per cell also increased between passages 60 and 68 (see Fig. 4). However, with further following of these cells, by passage 74 the DMs essentially disappeared from the HL-60 cell (see Fig. 4). The karyotype was also noted to change with increasing cell passage. Chromosome analysis of passages 60-63 revealed a modal chromosome number of 45 with the following karyotype: $45, X,-X$, $-5,-17,+18,9 p-, 10 p+, 14 q-, 16+, 16 q+,+\operatorname{der}(5) t(5 ; 17)$

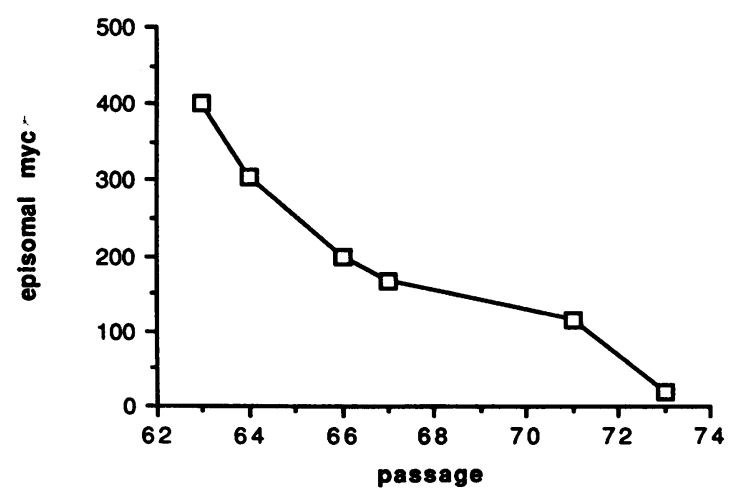

Figure 2. HL-60 subclones were passaged as described in the text and assayed for the amount of c-myc present on episomal DNA using the alkaline lysate technique and standard gel electrophoresis technique described above. The amount of c-myc present as episomal DNA was quantitated by densitometry of films done from Southern transfer from the electrophoresis gels. The amount of c-myc present on episomal DNA declined from 400 density units on passage 63 cells down to nearly undetectable amounts of c-myc present on episomal DNA by passage 73 . (q11.2;q?11.2), +DM (stem line 1). By passage 70, a second stem line was apparent showing the following: $44, X,-X$, $-5,-8-17,-17,+18,9 p-, 10 p+, 14 q-, 16 q+, 16 q+,+\operatorname{der}(5)$ $\mathrm{t}(5: 17)$ (q11.2; q?11.2) $+\operatorname{der}(5) \mathrm{t}(5 ; 17)$ (q11.2; q?11.2) (stem line 2 ). This accounted for $60 \%$ of cells and showed no DMs.
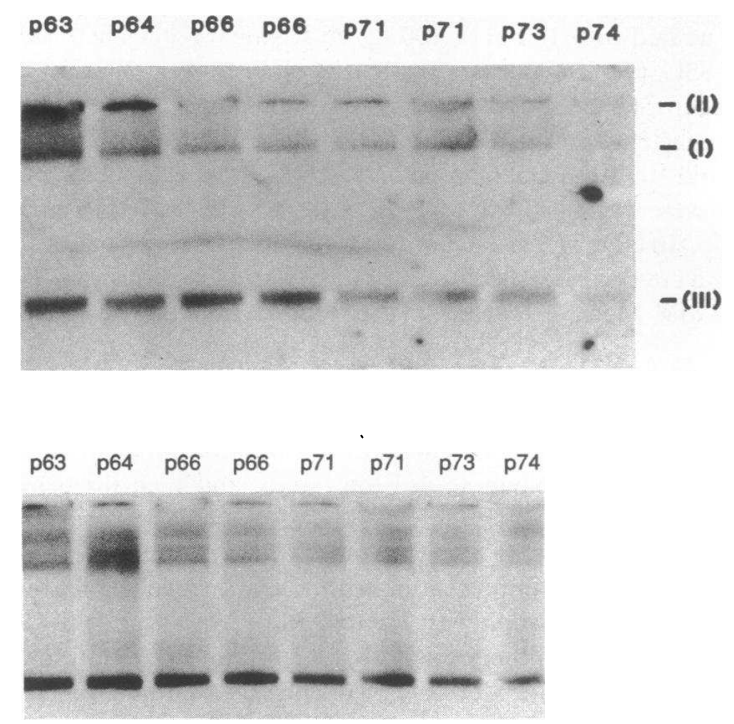

Figure 3. (Top) Decline in the amount of c-myc present on episomal DNA for one representative subclone (no. 173). The cell line was followed from passage 63 to passage 74 with alkaline lysates done as described in text and gel electrophoresis performed on the lysates. After Southern transfer, the membrane was then hybridized with a c-myc probe. Note the decline in c-myc signal of all three forms of the episomal DNA (forms I, II, and III) with increased passage of the subclones. Also note the good reproducibility of the assay when two different alkaline lysate procedures were performed on the same passage (passages 66 and 71). (Bottom) Same blot washed and reprobed with pET5 mitochondrial DNA sequence to document amount of alkaline lysate DNA loaded in each lane. 


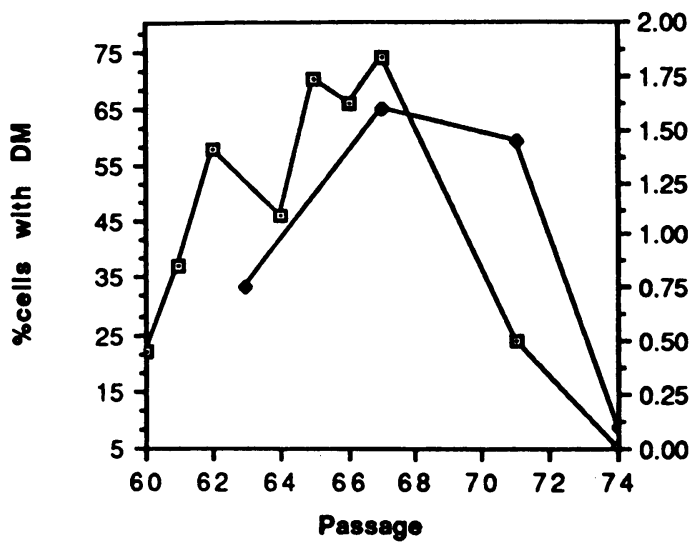

Figure 4. HL-60 cells passaged in culture were evaluated for the percentage of cells with double minutes $(\square)$ (50 metaphase spreads examined; see Methods for details). The percentage of cells with double minutes increased from $20 \%$ to $75 \%$ from passage 60 to 68 but decreased by passages 71 and 74 . The average number of double minutes per cell followed a similar pattern ( $\square$ ).

The duplicated $\operatorname{der}(5)$ appeared to have a slightly larger short arm region in some cells. This duplicated chromosome may have arisen by a non-disjunction event. By passage $75,90 \%$ of cells were from the stem line 2 and practically no DMs were seen. These surprising results were studied at the molecular level to ascertain what was happening to the $c-m y c$ sequences.

To determine whether $c-m y c$ sequences were located on the double-minute DNA we utilized a new gel technique suited for isolation of large (1-9 mbp)-sized DNA. DMs visible on light microscopy are thought to be at least 1-2 mbp in size. The new gel technique is called CHEF electrophoresis $(28,29)$. This technique was performed on passages of the HL-60 cells known to contain DMs (passages 64-72) and cells in which DMs could no longer be detected cytogenetically (passage 74). As can be seen in Fig. 5, there are distinct c-myc containing species at sizes of $1.5 \mathrm{mpb}$ and at approximately twice that size. These are the appropriate sizes for double-minute DNA (30). Double-minute DNA running in this position has also been described for other cell lines (30). Also of note in Fig. 5 is that the signal intensity for the double-minute DNA signal appears to decrease with increasing passage number. However, the intensity of signal in the zone of compression increases in intensity. The zone of compression contains very large DNA molecules possessing c-myc sequences. These probably represent chromosomal incorporation of the c-myc sequence. To explore that possibility we have performed in situ hybridizations on these later passage cells. As can be seen in Fig. 6, $c-m y c$ has integrated into the short arm of the duplicated derived chromosome $5, \operatorname{der}(5) t(5 ; 17)(\mathrm{q} 11.2 ; \mathrm{q}$ ?11.2) in the cells. This localization was documented in every single one of the 50 different metaphases examined. Thus, with both molecular and cytogenetic techniques, it appears that with continued passage of the HL-60 cells, c-myc sequences integrate into chromosomal DNA. It is of note that Wolman and colleagues (34) have previously documented that amplified c-myc was localized to the long arm of a marker chromosome M3q+, which appears to be similar to the der(5) described here.

Fig. 7 summarizes the c-myc sequence data from the alkaline lysate and the CHEF techniques. As can be seen in this figure, as the amount of c-myc in the episome decreases, there is an increase in c-myc sequences in double-minute DNA. As the amount of $c-m y c$ sequences on the DMs decrease the amount of c-myc sequences present on chromosomal DNA increases. We have now followed these cells with karyotype examination and CHEF gels for 26 additional passages (up to passage 100) and to date have found no evidence of transfer of the c-myc sequences back into the double minute or episomal compartments.

Effect of movement of c-myc on cell-doubling time. The populations doubling times of the HL-60 cells were followed with increasing passage number. As can be seen in Table I, as the cells are passaged the population doubling time becomes progressively shorter. By the time the chromosomal integration of c-myc has taken place, the doubling time has fallen to $44.1 \mathrm{~h}$.
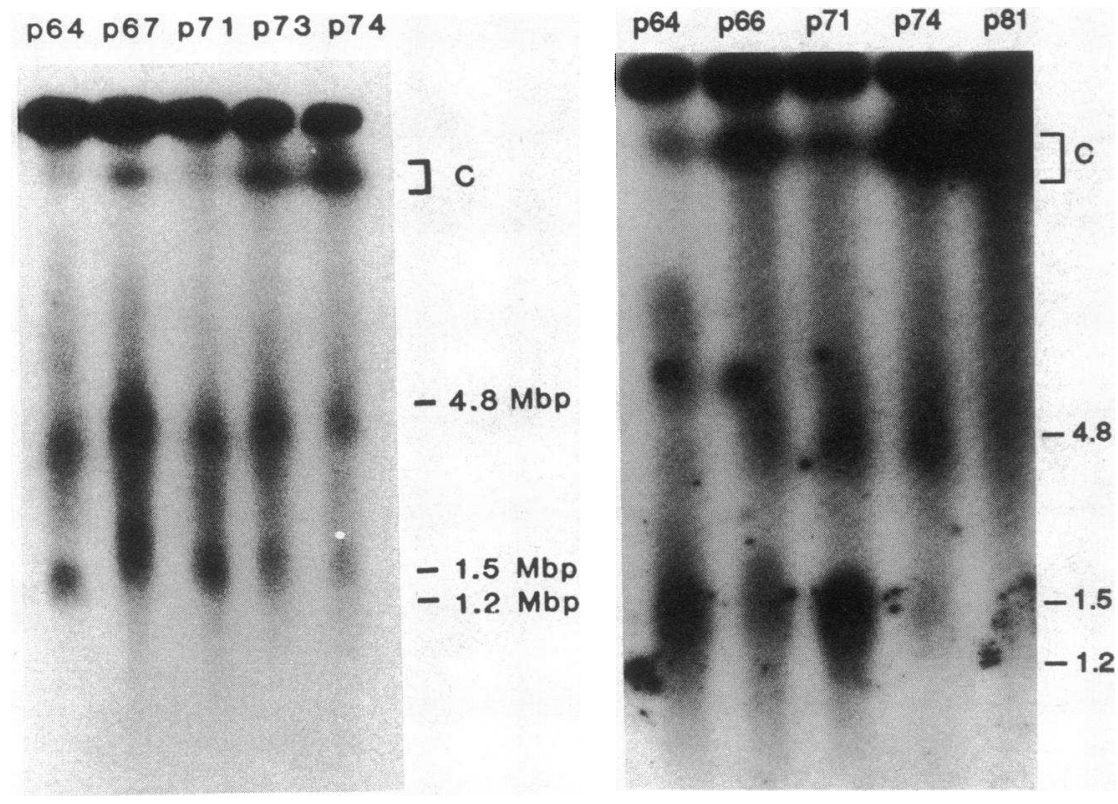

Figure 5. (Left) CHEF gel electrophoresis run on passages 64 through 74 of the HL-60 cells (see text for details). After Southern transfer from the gel, the membrane was probed with a c-myc probe. Bands are visible in the $1.5 \mathrm{mbp}$ range and in the $<4.8 \mathrm{mbp}$ range. These signals probably represent c-myc sequences on double minute DNA (30). Note that by passage 74 these signals are less intense. However, the c-myc signals in the zone of compression $(c)$, thought to represent chromosomally incorporated sequences, increase in intensity over passages 73 and 74. (Right) Same experiment repeated with intermediate (passage 66) and later passage cells (passage 81) demonstrating same trend. 

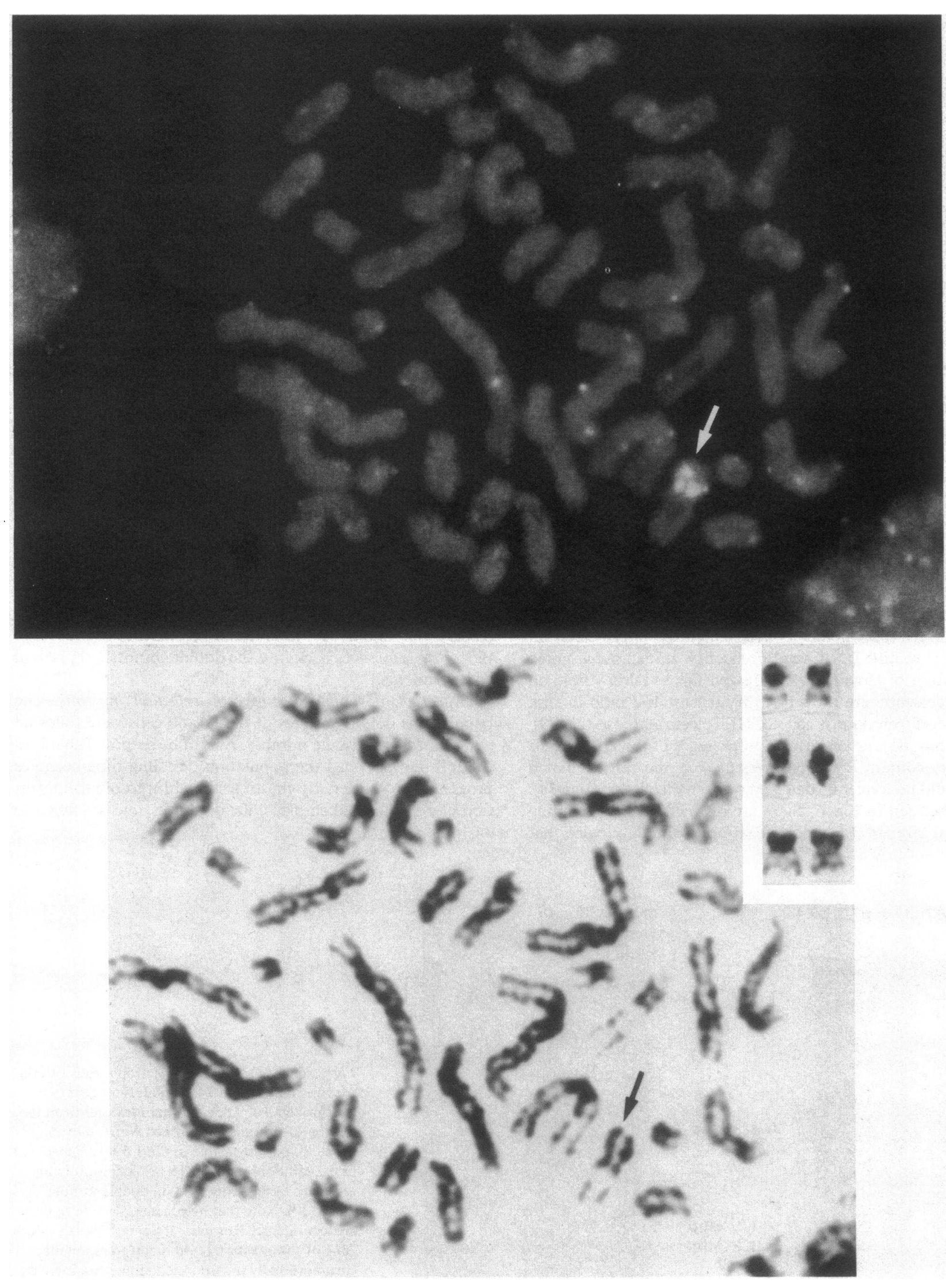


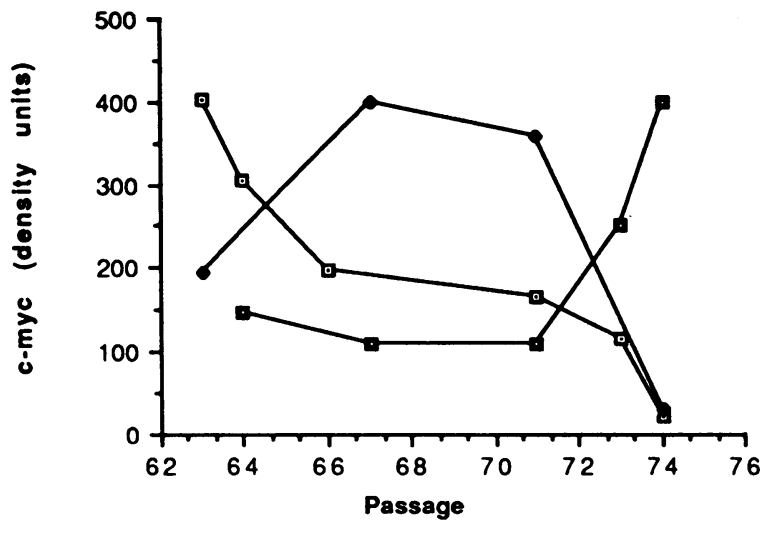

Figure 7. Composite of c-myc sequence localization data. Note that c-myc sequence (determined from densitometry from electrophoresis gels) is located in the episomal compartment in early passages of the cells $(\square)$. It shifts to the double minute compartment with maximal localization there between passages 67 and $71(\diamond)$. It finally shifts to the chromosomal compartment by passage 74 (ब). The amount of c-myc ( $y$-axis) is expressed in densitometry units.

\section{Discussion}

Molecular and cytogenetic evidence has been presented to support the concept that extrachromosomal DNA (episomes) containing c-myc sequences in earlier passages of the human HL-60 cell line are replaced in later passages of the line by larger structures identifiable as DMs. Evidence is also presented to indicate that with further passage in culture these c-myc sequences appear in chromosomal sites. Thus the c-myc sequences appear to evolve from the episomal compartment to a double minute compartment (both of these being extrachromosomal DNA) and finally into an intrachromosomal compartment (see Fig. 7 for a summary). What is quite surprising is the rapidity with which this transfer to different compartments occurs (over a period of 10 passages [with cell passages done two times per week = a period of $35 \mathrm{~d}]$ ). One possible mechanism for this rapid change is that the population with the chromosomally incorporated c-myc becomes the predominant population because the generation time for that population is shorter than for the population of cells which have episomes or DMs. Biedler and colleagues (35) have previously noted that human neuroblastoma cell lines with homogeneously staining regions have shorter generation times than do double minutecontaining cell lines. Another possible explanation for the rapid change in the population is a parallel, but not simultaneous evolution of episomes to DMs and to HSRs. Our cytogenetic evidence is also compatible with that possibility.

Other investigators have previously presented cytogenetic evidence that HSRs appear as DMs disappear. Biedler et al. (35) first presented the concept of a reciprocal relationship
Table I. Cell Population Doubling Time for the HL-60 Cells in Serial Passage

\begin{tabular}{cc}
\hline Passage number & Cell population doubling time \\
\hline & $h$ \\
$9^{*}($ ref 44$)$ & $55-60$ \\
63 & 48 \\
71 & 45.4 \\
75 & 44.1 \\
\hline
\end{tabular}

* See Gallagher et al. (44).

between the appearance of HSRs and the disappearance of DM-containing cells in two human neuroblastoma cell lines (SK-N-MC and NAP). Levan et al. (36-38) noted the appearance of "CM" (c-minus) chromosomes or abnormal banding regions (ABRs) and disappearance of DMs in the mouse SEWA ascites tumor line. Cowell (40) has observed that an in vitro transformed mouse salivary gland epithelial cell line had DMs observed in $100 \%$ of cells at early passage. After 17 in vitro passages a subpopulation of cells appeared that had no DMs but contained an HSR on chromosome $5(39,40)$. Similar findings have been reported by George and Powers (41) in a mouse adenocortical cell line and by Quinn et al. (42) in a human neuroendocrine tumor cell line. Most recently, Trent and colleagues (43) have described a newly biopsied human malignant melanoma that had an HSR on chromosome 7 in only 1 of 110 cells whereas 99 of the 110 cells had multiple DMs. When the tumor was established in culture, by passage 9 in vitro, $100 \%$ of the cells had an HSR on chromosome 7 and no DM-containing cells were observed. All of these prior studies as well as the present study suggest a selection for HSR-or ABR-bearing cells with increasing passages in culture.

Other workers have recognized a variety of changes in the cytogenetics of the HL-60 cell line over time. Gallagher and colleagues (44) noted the tumor from the patient and the cell line (passages 6-55) had only "occasionally observed" cells with DMs. Other abnormalities included deletion of chromosomes $X, 5,8$, and 17 with the appearance of a submetacentric marker chromosome (M3).

Norwell and colleagues (45) examined karyotypes of HL-60 cells frozen in 1978 and found in their cells (passage number not given), that "nearly all metaphases contained numerous DMs." In HL-60 cells frozen 1 year later (1979), they noted a normal chromosome 8 had been replaced with an $8 \mathrm{q}+$ chromosome with an abnormal banding pattern (45). Of particular note, DMs were not observed in any of the cells. These findings were also noted in HL-60s kept in continuous passage since 1978. Thus they presented indirect evidence that c-myc was amplified in the HL-60 leukemia line originally in DMs

Figure 6. In situ hybridizations were carried out on passage 74 cells (see text for details). (Upper panel) In this representative metaphase with hybridization with the c-myc probe, there is increased signal noted over an area of a marker 3 chromosome (arrow); (lower panel) by borate banding patterns (arrow), this signal appears to be a chromosome derived from chromosomes 5 and 17 (der5p; 17q). Some signal on chromosome 8 was noted in some metaphase spreads but there was clearly no increased hybridization in the native gene locus. (Lower panel inset) Gbanding of partial karyotypes of three cells showing two copies of the der(5)t(5;17)(q11.2;q?11.2). The right chromosome in each pair is suggestive of increased p-arm material above the centromere. 
which progressed to c-myc amplification on an abnormal banding region on $8 \mathrm{q}$. This finding of amplification of c-myc on an ABR on chromosome 8 was of particular note because later the native locus of $c-m y c$ was found to be $8 \mathrm{q} 24(46-48)$.

Wolman and colleagues (34) studied approximately passage 50 of the HL-60 line. They noted a modal chromosome number of 45 with losses of no. 5 , no. 17 , and $X$, and a gain of no. 18 and the presence of a number of markers including an $\mathrm{M} 3 \mathrm{q}+$. They found no cells with multiple minutes and noted fewer than $1 \%$ of metaphases had possible DMs. The M3q+ was interpreted as a translocation $t(5 p ; 17 q)$. The ABRs on $\mathrm{M} 3 \mathrm{q}+$ were found to be the site of the amplified c-myc. They concluded the breakpoint on chromosome 17 in 17q21 was the area where the c-myc DNA sequences were inserted. Basically their work documented that, if DMs do integrate into a chromosome, "it is not obligatory that the native region of the gene be involved in the integration event" (34). They postulated that the mobile form of the c-myc will seek a region susceptible to breakage or "take advantage of ongoing breakage and reunion events." Our data indicate that the c-myc sequences on the double minutes incorporated into a duplicated chromosome, supporting the concept that it make take a duplication event to get incorporation.

Misawa et al. (49) recently examined HL-60 cell lines (passages not designated) one of which had the ABR on chromosome 8 (with no DMs), reported by Nowell et al. (45), while the other had DMs but no abnormality of chromosome 8 . In situ hybridization studies demonstrated localization of $c-m y c$ to the ABR in the one cell line and to the DMs in the other. These data were consistent with the concept that these chromosomal abberations were interchangeable.

As noted above, gene amplification has been described for both oncogenes and drug resistance genes in patients' tumors. The two cytogenetic manifestations of gene amplification are double minutes and homogeneously staining regions (also known as expanded chromosomal regions or abnormally banding regions). Since DMs do not have a centromere they segregate randomly at each mitosis and consequently are lost from the population over time unless there is some selective pressure to give cells with amplified sequences on DMs a growth advantage. On the other hand, if amplified sequences are located on expanded chromosomal regions (HSRs), they segregate normally during mitosis and are probably not lost even in the absence of selection $(1,11,23)$.

In the present study we have identified a time in the passage of HL-60 human promyelocytic leukemia cells during which the c-myc sequences are located on extrachromosomal sites (first on episomes, then later on DMs). It is conceivable these c-myc sequences might be vulnerable to loss while they are on these extrachromosomal sites. Loss of the c-myc sequences could be associated with a less aggressive biologic behavior. However, once the c-myc sequences are located on the chromosome it is unlikely the oncogene sequences can be eliminated.

Several strategies have been proposed to eliminate extrachromosomal DNA gene sequences. Therefore, knowing that oncogene sequences or drug resistance gene sequences are on extrachromosomal DNA makes a strategy for elimination of the extrachromosomal sequences (for therapeutic reasons) a possibility $(20,23,24,50)$. Since it has recently been demonstrated that human tumors taken directly from patients more often have DMs present than HSRs, this strategy may have some clinical application (Benner, S. E., G. M. Wahl, and D. D. Von Hoff, manuscript submitted for publication).

Our work has not addressed the question of how the episomes arise. They are present in the earliest passages of the line. Wahl (23) has proposed that some insult to the cell causes perturbation of DNA synthesis which leads to stalled replication loops, excision of which result in the formation of episomes. As of now, there is no definite proof this is the case. However, it is an area of active investigation.

\section{Acknowledgments}

The authors are grateful to Drs. Geoffrey Wahl, Phil Serwer, and Sam Friedberg for their helpful discussions, to Dr. Dan Pinkel of Laurence Livermore Laboratories for assistance with the in situ techniques, and to Clair Waggoner and Julia Perkins for valuable secretarial assistance.

This study was supported by grants from the National Foundation for Cancer Research and the American Institute for Cancer Research.

\section{References}

1. Stark, G., and G. M. Wahl. 1984. Gene amplification. Annu. Rev. Biochem. 53:447-491.

2. Schimke, R. T. 1984. Gene amplification in cultured cells. Cell. 37:705-713.

3. Schimke, R. T. 1984. Gene amplification, drug resistance and cancer. Cancer Res. 44:1735-1742.

4. Stark, G. R. 1986. DNA amplification in drug resistant cells and in tumors. Cancer Surv. 5:1-23.

5. Alitalo, K., and M. Schwab. 1985. Oncogene amplification in tumor cells. Adv. Cancer Res. 47:235-281.

6. Brodeur, G. M., R. C. Seeger, M. Schwab, H. E. Varmus, and J. M. Bishop. 1984. Amplification of N-myc in untreated human neuroblastomas correlates with advanced stage disease. Science (Wash. DC). 224:1121-1124.

7. Slamon, D. J., G. M. Clark, S. G. Wong, W. J. Levin, A. Ullrich, and W. L. McGuire. 1987. Human breast cancer: correlation of relapse and survival with amplification of the HER-2/neu oncogene. Science (Wash. DC). 235:177-182.

8. Barker, P. E. 1982. Double minutes in human tumor cells. Cancer Genet. Cytogenet. 5:81-94.

9. Cowell, J. K. 1982. Double minutes and homogeneously staining regions: gene amplification in mammalian cells. Annu. Rev. Genet. 16:21-59.

10. Spriggs, A. I., M. M. Boddington, and G. M. Clark. 1962. Chromosomes of human cancer cells. Br. Med. J. 2:1431-1435.

11. Biedler, J. L., and B. A. Spengler. 1976. Metaphase chromosome anomaly: association with drug resistance and cell specific product. Science (Wash. DC). 191:185-187.

12. Biedler, J. L., and B. A. Spengler. 1976. A novel chromosome abnormality in human neuroblastomas and antifolate resistant Chinese Hamster cell lines in culture. J. Natl. Cancer Inst. 57:683-695.

13. Balaban-Malenbaum, G., and F. W. Gilbert. 1977. Double minute chromosomes and the homogeneously staining regions in chromosomes of human neuroblastoma cell lines. Science (Wash. DC). 198:739-741.

14. Balaban-Malenbaum, G., and F. W. Gilbert. 1980. Relationship between homogeneously staining regions and double minute chromosomes in human neuroblastoma cell lines. In Advances in Neuroblastoma Research. Volume 12. A. E. Evans, editor. Raven Press, New York. 97-107.

15. Schimke, R. T., R. J. Kaufman, F. W. Alt, and R. F. Kellems. 1978. Gene amplification and drug resistance in cultured murine cells. Science (Wash. DC). 202:1051-1055. 
16. Smith, G. R. 1976. Evolution of repeated DNA sequences by unequal crossover. Science (Wash. DC). 191:528-535.

17. Schimke, R. T., P. C. Brown, R. J. Kaufman, M. McGrogan, and D. L. Slote. 1981. Chromosomal and extrachromosomal localization of amplified dihydrofolate reductase genes in cultured mammalian cells. Cold Spring Harbor Symp. Quant. Biol. 45:785-796.

18. Carroll, S. M., P. Gaudray, M. L. DeRose, J. F. Emerh, J. L. Meinkoth, F. Nakkin, M. Subler, D. D. Von Hoff, and G. M. Wahl. 1987. Characterization of an episome produced in hamster cells that amplify a transfected CAD gene at high frequency: functional evidence for a mammalian replication origin. Mol. Cell Biol. 7:1740-1750.

19. Carroll, S. M., M. L. DeRose, P. Gaudray, C. M. Moore, D. R. Needham-VanDevanter, D. D. Von Hoff, and G. M. Wahl. 1988. Double minute chromosomes can be produced from precursors derived from a chromosomal deletion. Mol. Cell Biol. 8:1525-1533.

20. Von Hoff, D. D. Extrachromosomal circular DNA (episome) formation as a new mechanism for drug resistance and tumor progression. 1989. Invest. New Drugs. 7:439. (Abstr.)

21. Maurer, B. J., E. Lai, B. A. Hamkalo, L. Hood, and G. Attardi. 1987. Novel submicroscopid extrachromosomal elements containing amplified genes in human cells. Nature (Lond.). 327:434-437.

22. Ruiz, J. C., K. Choi, D. D. Von Hoff, I. B. Roninson, and G. M. Wahl. 1989. Autonomously replicating episomes containing $\mathbf{m d r l}$ genes in a multidrug resistant human cell line. Mol. Cell Biol. 9:109115.

23. Wahl, G. M. 1989. The importance of circular DNA in mammalian gene amplification. Cancer Res. 49:1333-1340.

24. Von Hoff, D. D., D. R. Needham-VanDevanter, J. Yucel, B. F. Windle, and G. M. Wahl. 1988. Amplified human MYC oncogenes localized to replicating submicroscopic circular DNA molecules. Proc. Natl. Acad. Sci. USA. 85:4804-4808.

25. Collins, S. J., R. C. Gallo, and R. F. Gallagher. 1977. Continuous growth and differentiation of human myeloid leukaemic cells in suspension culture. Nature (Lond.). 270:347-349.

26. Collins, S., and M. Groudine. 1982. Amplification of endogenous myc-related DNA sequences in a human myeloid leukaemic cell line. Nature (Lond.). 298:679-681.

27. VanDevanter, D. R., H. M. Trammell, and D. D. Von Hoff. 1989. Simple construction of rubber-based agarose block molds for pulsed-field electrophoresis. BioTechniques. 7:143-144.

28. Cantor, C. R., C. L. Smith, and M. V. Mathew. 1988. Pulsedfield electrophoresis of very large DNA molecules. Ann. Rev. Biophys. Chem. 17:287-304.

29. Lai, E., B. W. Birren, S. M. Clark, M. T. Simon, and L. Hood. 1989. Pulsed field gel electrophoresis. Biotechniques. 7:34-42.

30. Van der Bliek, A. M., C. R. Lincke, and P. Borst. 1988. Circular DNA of 3T6R50 double minute chromosomes. Nucleic Acids Res. 16:4841-4851.

31. Meinkoth, J., and G. M. Wahl. 1984. Hybridization of neucleic acids immobilized on solid supports. Anal. Biochem. 138:267-284.

32. Hozier, J. C., and L. L. Lindquist. 1980. Banded karyotypes from bone marrow: a clinically useful approach. Human Genet. 53:205-209.

33. Pinkel, Dr., T. Straume, and T. W. Gray. 1986. Cytogenetic analysis using quantitative, high sensitivity, fluorescence hybridization. Proc. Natl. Acad. Sci. USA. 83:2934-2938.

34. Wolman, S. R., L. Lanfrancone, R. Dalla-Favera, S. Ripley, and A. S. Henderson. 1985. Oncogene mobility in a human leukemic line HL60. Cancer Genet. Cytogenet. 17:133-141.

35. Biedler, J. L., M. B. Meyers, and B. A. Spengler. 1983. Homogeneously staining regions and double minute chromosomes, preva- lent cytogenetic abnormalities of human neuroblastoma cells. Adv. Cell Neurobiol. 4:268-307.

36. Levan, A., G. Levan, and N. Mandahl. 1978. A new chromosome type replacing the double minutes in a mouse tumor. Cytogenet. Cell Genet. 20:12-23.

37. Levan, A., G. Levan, and N. Mandahl. 1981. Double minutes and C-bandless chromosomes in a mouse tumor. In Genes, Chromosomes, and Neoplasiz. F. E. Arrigh, P. N. Rao, and E. Stubblefield, editors. Raven Press, New York. 223-251.

38. Levan, G., and A. Levan. 1982. Transitions of double minutes into homogeneously staining regions and c-bandless chromosomes in the SEWA tumor. In Gene Amplification. R. T. Schimke, editor. Cold Spring Harbor Laboratory, Cold Spring Harbor, NY. 91-97.

39. Cowell, J. K. 1980. A new chromosome region possibly derived from double minutes in an in vitro transformed epithelial cell line. Cytogenet. Cell Genet. 27:2-7.

40. Cowell, J. K. 1981. Chromosome abnormalities associated with salivary gland epithelial cell lines transformed in vitro and in vivo with evidence for a role for genetic inbalance in transformation. Cancer Res. 41:1508-1517.

41. George, D. L., and V. E. Powers. 1982, Amplified DNA sequences in $\mathrm{Y} 1$ mouse adrenal tumor cells: association with double minutes and localization to a homogeneously staining chromosomal region. Proc. Natl. Acad. Sci. USA. 79:1597-1601.

42. Quinn, L. A., G. E. Moore, R. T. Morgan, and L. K. Woods. 1979. Cell lines from human colon carcinoma with unusual cell products, double minutes, and homogeneously staining regions. Cancer Res. 39:4914-4924.

43. Trent, J. M., F. H. Thompson, and C. Ludwig. 1984. Evidence for selection of homogeneously staining regions in a human melanoma cell line. Cancer Res. 44:233-237.

44. Gallagher, R., S. Collins, J. Trujillo, K. MoCredie, M. Ahearn, S. Tsai, R. Metzgar, G. Aulakh, R. Ting, F. Ruscetti, and R. Gallo. 1979. Characterization of the continuous, differentiating myeloid cell line (HL60) from a patient with acute promyelocytic leukemia. Blood. 54:713-733.

45. Nowell, P., J. Finon, R. Dalla-Favera, R. C. Gallo, A. arRushdi, H. Romanczak, J. R. Selden, B. S. Enanuel, G. Rovera, and C. M. Croce. 1983. Association of amplified oncogene c-myc with an abnormally banded chromosome 8 in a human leukaemia cell line. Nature (Lond.). 306:494-497.

46. Dalla-Favera, R., M. Bregni, J. Erikson, D. Patterson, R. C. Gallo, and C. M. Croce. 1982. Human c-myc onc gene is located on the region of chromosome 8 that is translocated in Burkitt lymphoma cells. Proc. Natl. Acad. Sci. USA. 79:7824-7827.

47. Taub, R., I. Kirsch, C. Morton, G. Lenoir, D. Swan, S. Tronick, S. Aransa, and P. Leder. 1988. Translocations of the c-myc gene into the immunoglobulin heavy chain locus in human Burkitt lymphoma and murine plasmacytoma cells. Proc. Natl. Acad. Sci. USA. 79:78377841.

48. Ned, B. G., S. C. Jhanwan, R. S. K. Chagonto, and W. S. Hayward. 1982. Two human c-onc genes are located on the long arm of chromosome 8. Proc. Natl. Acad. Sci. USA. 79:7842-7846.

49. Misawa, S., S. P. Stool, and J. R. Testa. 1987. Amplification of the c-myc oncogene is associated with an abnormally banded region on chromosome 8 or double minute chromosomes in two HL60 human leukemia cell lines. Cancer Genet. Cytogenet. 28:127-135.

50. Snapka, R. M., and A. Varshavsky. 1983. Loss of unstably amplified dihydrofolate reductase genes from mouse cells is greatly accelerated by hydroxyurea. Proc. Natl. Acad. Sci. USA. 80:75337537. 